\title{
FUZZY MODELING IN ORANGE PRODUCTION UNDER DIFFERENT DOSES OF SEWAGE SLUDGE AND WASTEWATER
}

\author{
Fernando F. Putti ${ }^{1,2 *}$, Marcio H. Lanza ${ }^{2}$, Hélio G. Filho², Camila P. Cremasco', \\ Angela V. Souza ${ }^{1}$, Luís R. A. Gabriel Filho ${ }^{1}$
}

${ }^{2 *}$ Corresponding author. São Paulo State University (UNESP), School of Sciences and Engineering, Tupã - SP, Brazil. E-mail: fernando.putti@unesp.br | ORCID ID: http://orcid.org/0000-0002-0555-9271

\section{KEYWORDS}

Fuzzy logic, organic matter, biosolid, reuse water, Mamdani method.

\begin{abstract}
The present work aimed to develop mathematical fuzzy models to evaluate the effects of different doses of sewage sludge and irrigation with wastewater and potable water. Such models were elaborated from an experiment carried out at the Faculty of Agronomic Sciences, in the Department of Soil and Environmental Resources, from the Sao Paulo State University, in Brazil. The experiment was carried out in a randomized block design, in a $6 \times 2$ factorial scheme, with 6 doses of sewage sludge $(0,25,50,75,100$ and 125 of the recommended dose of $\mathrm{N}$ ), and in the presence and absence of wastewater. In the development of the fuzzy model, the Mamdani method was used for the defuzzification. As input variables, the doses of sewage sludge and the types of water were used. For the output variables, it was sought to evaluate the biometric and developmental components of the culture. It can be inferred that the model developed presented a good fit when compared to the regression model, and that the use of sewage sludge may prove to be a potential future replacement of mineral nitrogen.
\end{abstract}

\section{INTRODUCTION}

Population growth in the last decades has been causing basic sanitation problems (Herrera, 2019), which can be observed in the declining quality of river water, a result of the lack of sewage treatment. Oftentimes, wastewater is dumped into rivers without any treatment (Kibena et al., 2014; Donoso \& Rios-Touma, 2020).

Many rivers are used as receiving bodies of wastewater from urban centers. However, farming areas close to these centers have used such contaminated water to irrigate crops (Brion et al., 2015; Miller-Robbie et al., 2017).

Several researchers have been investigating the effects of residuary water on different crops since there are research gaps to be studied. Some studies have assessed the behavior of wastewater in the soil and crops, such as in Bedbabis et al., (2014, 2015) and Ma et al., (2015). There are also studies assessing the behavior of sewage sludge, such as those of Latare et al., (2014), Shaheen et al., (2014), Song et al., (2014), Waqas et al., (2014), Bourioug et al., (2015), and Yuan et al., (2016).
Such research gaps on this subject can be associated mainly with the origins of sewage sludge and wastewater, as they can be organic or contain high levels of heavy metals (Costa et al., 2009; Passos Rangel et al., 2006).

The real effect of wastewater and sewage sludge can be assessed using statistical models. The present study seeks to prove the feasibility of using mathematical models based on fuzzy logic. These models enable generalizing results and making specific analyses of nontested intervals (Blanco-Fernández et al., 2014; Ross, 2010; Coppi et al., 2006).

Fuzzy logic-based models have been used to analyze the effects of global warming on orchids (Putti et al., 2014; 2017a, 2017b), cotton crop management practices (Papageorgiou et al., 2009), herbicide spraying (Yang et al., 2003), sewage sludge and wastewater quality (Kalavrouziotis et al., 2016), evapotranspiration (Patel et al., 2014), and effect of water deficit and saline stress on tomato crops (2019a, 2019b)

${ }^{1}$ São Paulo State University (UNESP), School of Sciences and Engineering, Tupã - SP, Brasil.

${ }^{2}$ São Paulo State University (UNESP), School of Agriculture, Botucatu - SP, Brasil.

Area Editor: Jefferson Vieira José

Received in: 5-25-2019

Accepted in: 1-12-2021 
The objective of this study was to develop a fuzzy model to evaluate the productivity of citrus orchards under different doses of sewage sludge and wastewater irrigated.

\section{MATERIAL AND METHODS}

\section{Description of the experiment}

The study was carried out at the Department of Soil and Environmental Resources, Faculty of Agricultural Sciences of the São Paulo State University (FCA/ UNESP), Campus of Botucatu, São Paulo State, Brazil. The soil used in the experiment is classified as dystrophic Red Latosol (Oxisol) by the Brazilian Agricultural Research Corporation (EMBRAPA, 2006).

The cultivar of sweet orange 'Valencia' was used in the experiment. The cultivar Swingle of citrumelo was used as rootstock, as it is highly commercialized and resistant to pests and diseases.

The experiment performed in 500-L containers filled with soil. These were spaced $5 \mathrm{~m}$ within rows and 4 $\mathrm{m}$ between rows. Treatments consisted of six sewage sludge doses (equivalent to $0,25,50,75,100$, and $125 \%$ of the recommended nitrogen dose) and two water sources for irrigation (potable and wastewater). The experiment was carried out in a $6 \times 2$ factorial scheme, with 6 repetitions. Nitrogen dose was supplemented to $100 \%$ by mineral $\mathrm{N}$ application, and complementary $\mathrm{N}$ topdressing was performed.

The amount of $\mathrm{N}$ available in composted sewage sludge was calculated according to the Resolution of the National Environment Council n ${ }^{\circ}$ 375/2006 (BRASIL, 2006), which establishes a mineralization rate for composted sewage sludge at $10 \%$. However, we considered a mineralization rate of $30 \%$ since $10 \%$ is specific for temperate soils, which have different conditions compared to tropical soils (Andrade et al., 2010). The amount of composite sewage sludge to be applied was estimated based on the following information: 1) a sludge moisture content of $30 \%, 2$ ) crop $\mathrm{N}$ demand of $300 \mathrm{~g}$ per plant (Quaggio et al., 1996), and 3) $100 \mathrm{~kg}$ sewage sludge has, on a dry basis, 1.07 $\mathrm{kg} \mathrm{N}$. Since $30 \%$ of $\mathrm{N}$ in sludge is mineralized, the doses (on a dry base) were about $0,24,48,72,96$, and $120 \mathrm{~kg}$ per plant, which correspond to $0,25,50,75,100$, and $125 \%$ of the $\mathrm{N}$ recommendation for citrus, respectively. These recommended doses were divided into two applications, with an interval of 90 days (August and November).
The irrigation was carried out daily, in order to replace the loss by evapotranspiration of the crop, which was measured using the class A tank. And it was determined using [eq. (1)]:

$$
L_{a p}=\frac{E C \cdot K p \cdot K c}{E f}
$$

Where:

$L_{a p}$ - applied blade (\%);

$E c$ - evaporation obtained by the Class A tank;

$K p$ - Class A tank coefficient;

$K c$ - crop coefficient,

$E f$ - system efficiency.

Irrigation efficiency was considered as $95 \%$ since we used a drip system and $K c$ was 0.65 . The effects of treatments were analyzed using plant biometric parameters and production.

\section{Method of elaboration of the fuzzy system}

The mathematical fuzzy model proposed in this study sought to explain the agronomic traits of sweet orange plants irrigated with wastewater and sewage sludge doses.

According to Lanza (2014), management was performed using different doses of sewage sludge $(0,25$, $50.75,100,125 \%$ of the recommended dose of $\mathrm{N}$ ), and different types of water (potable and wastewater). And the characteristics of agronomic productivity to be used in this work were the biometric variables.

Considering a model of agronomic characteristics, we have $f: \mathbb{R}^{2} \rightarrow \mathbb{R}^{12}$, with $y=f(x)$, where $\mathbb{R}$ is the set of real numbers, where $x=\left(x_{1}, x_{2}\right)$ ) is defined by $x_{1}=$ sewage sludge doses ( $\%$ of recommended $\mathrm{N})$ and $x_{2}=$ type of water adopted for irrigation (Potable Water (0) or Wastewater (1)), with $x_{2} \in\{0.1\}$, and $y=\left(y_{1}, \ldots, y_{12}\right)$, is defined by the averages of the values of the biometric characteristics, namely $y_{1}=$ Stem Diameter , $\mathrm{y}_{2}=$ Crown Diameter, $\mathrm{y}_{3}=$ Plant Height, $\mathrm{y}_{4}=$ Canopy Volume, $\mathrm{y}_{5}=$ Number of Fruits, $\mathrm{y}_{6}=$ Total weight of 10 fruits, $\mathrm{y}_{7}=$ Production, $\mathrm{y}_{8}=$ Unitary Weight, $\mathrm{y}_{9}=$ Weight of 10 Fruits, $\mathrm{y}_{10}=$ Juice, $\mathrm{y}_{11}=$ Weight Juice e $\mathrm{y}_{12}=$ Peel Weight.

FIGURE 1 represents the proposed model in which the inputs and outputs are observed.

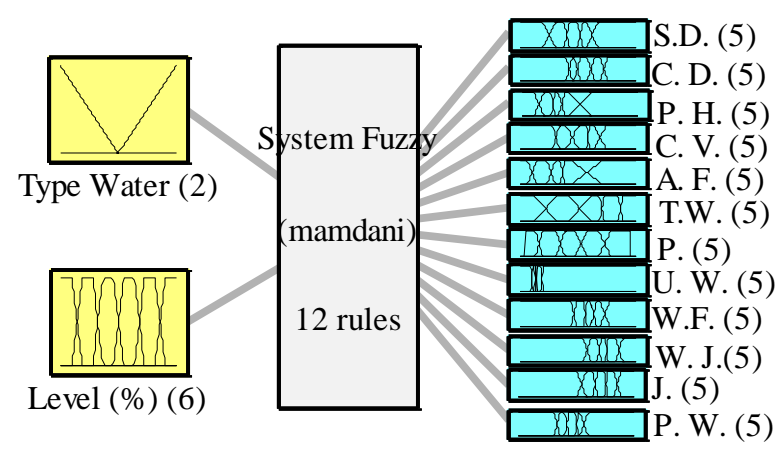

Description: Stem Diameter (S.D.), Crown Diameter (C.D.), Plant Height (P.H.), Canopy Volume (C.V.), Number of Fruits (N.F.), Total of 10 fruits (T.W.), Production (P), Unitary Weight (U.W.), Weight of 10 fruit (W.F.), Juice (J.), Weight Juice (W.J.), and Peel Weight (P.W.).

FIGURE 1. System based on fuzzy logic to evaluate the culture of oranges submitted to different doses of sewage sludge and types of water. 


\section{Developed Fuzzy Sets}

\section{Input variables}

To define the input variables 'Level of $\mathrm{N} \%$ ' and 'Water Type', fuzzy sets were adopted, of the trapezoidal type, because according to Yen (2009), this is a set that presents variable remains. Trapezoidal membership functions are better adapted to the model's response.

For the water type variable, 2 sets were adopted: one for Wastewater (WW) and one for Potable Water (PW). In this way, it was possible to carry out the elaboration of TABLE 1 and FIGURE 2, below.

TABLE 1. Definitions of fuzzy sets with their respective functions of the input variable 'Water'.

\begin{tabular}{ccc}
\hline Fuzzy Set & Type & Boundaries \\
\hline Wastewater & Triangular & {$\left[\begin{array}{lll}-0.5 & 0 & 0.5\end{array}\right]$} \\
Potable Water & Triangular & {$\left[\begin{array}{lll}0.5 & 1 & 1.5\end{array}\right]$} \\
\hline
\end{tabular}

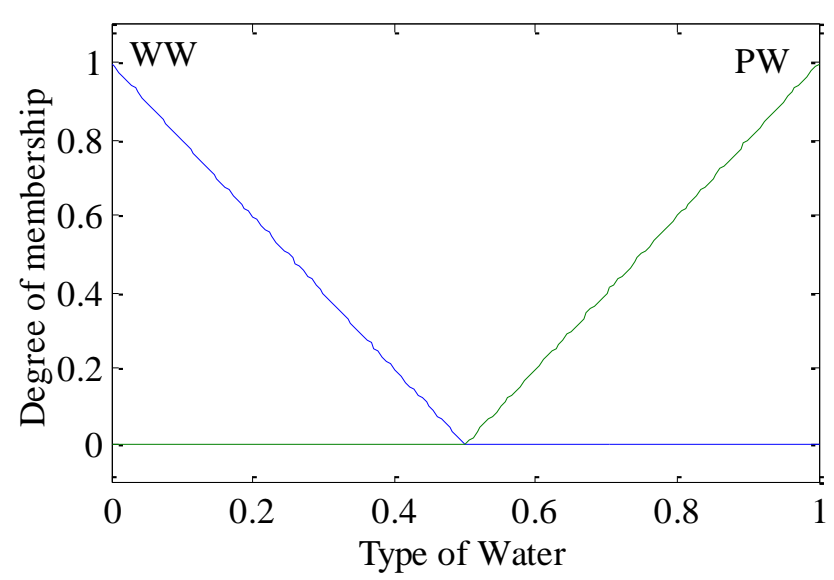

FIGURE 2. Membership functions for the fuzzy sets of the input variable 'Water Type'.

For the 'Level of N\%' variation, 6 sets were adopted, based on the levels established in the conducted experiment. They are called L1, L2, L3, L4 and L5, referring to the levels of $0 \%, 25 \%, 50 \%, 75 \%, 100 \%$ and $125 \%$ of the
Nitrogen dose, respectively. From the developed method, it was possible to develop

TABLE 2 and FIGURE 3, as follows.

TABLE 2. Definitions of the membership functions of the input variable 'Level of N\%'.

\begin{tabular}{|c|c|c|}
\hline Fuzzy Set & Type & Delimiter \\
\hline L1 & Trapezoidal & {$\left[\begin{array}{lllll}-1 & 0 & 22.72 & 11: 36\end{array}\right]$} \\
\hline L2 & Trapezoidal & {$\left[\begin{array}{lllll}11: 36 & 22.72 & 34.09 & 45.45]\end{array}\right.$} \\
\hline L3 & Trapezoidal & {$\left[\begin{array}{lllll}34.09 & 45.45 & 56.81 & 68.18\end{array}\right]$} \\
\hline L4 & Trapezoidal & {$\left[\begin{array}{lllll}56.81 & 68.18 & 79.54 & 90.9\end{array}\right]$} \\
\hline L5 & Trapezoidal & [ $\left.\begin{array}{lllll}79.54 & 90.9 & 102.27 & 113.63\end{array}\right]$ \\
\hline L6 & Trapezoidal & {$\left[\begin{array}{lllll}102.27 & 113.63 & 125 & 130\end{array}\right]$} \\
\hline
\end{tabular}

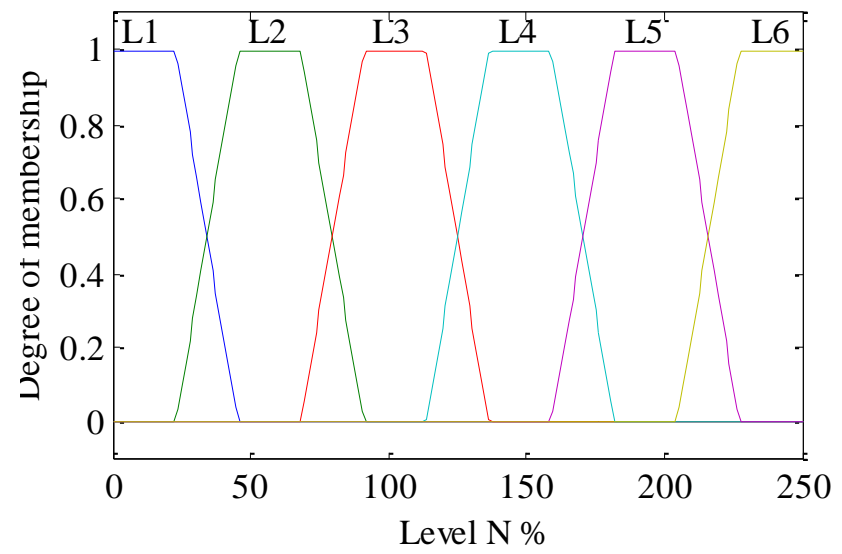

FIGURE 3. Membership functions defined for the fuzzy sets of the input variable 'Level of N\%'.

\section{Output variables}

In order to determine the fuzzy sets, the trapezoidal membership functions were developed. For the generalization of the method, since each variable has an amplitude, the set of each variable was considered as $100 \%$. Thus, the determination of the quartiles lower and upper limits was used to determine the coordinates (TABLE 3 ).

TABLE 3. Definitions of the membership functions of each output variable.

\begin{tabular}{ccc}
\hline Fuzzy Set & Type & Delimiters \\
\hline Very Low $($ VL) & Trapezoidal & [Lower limit - 1, lower limit, minimum, Q1] \\
\hline Low $(\mathrm{L})$ & Triangular & [minimum, Q1, Q2] \\
\hline Media $(\mathrm{M})$ & Triangular & {$[\mathrm{Q} 1, \mathrm{Q} 2, \mathrm{Q} 3]$} \\
\hline High $(\mathrm{H})$ & Triangular & {$[\mathrm{Q} 2, \mathrm{Q} 3$, Max] } \\
\hline Very High $(\mathrm{VH})$ & Trapezoidal & {$[\mathrm{Q} 3$, Maximum, High Limit, High Limit + 1] }
\end{tabular}




\section{Rule Base}

The elaborated rule base demonstrates how the fuzzy system models the results. Starting from the premise of the fuzzy rule, in which:

- If 'premise (antecedent)', then 'conclusion (consequent)', it was possible to calculate the outputs of the model, from the combination of the factors established as inputs.

Such an expression is referred to as the form of the rule based on cause and consequence. The rule base of the fuzzy model proposed was developed with a methodology similar to that used by Cremasco et al. (2010), Gabriel Filho et al. (2011, 2015, 2016), Pereira et al. (2008), Putti et al. (2014, 2017a, 2017b), Viais Neto et al. (2019a, 2019b), Martínez (2020), Góes (2021) and Matulovic et al. (2021). In this way, after the construction of the fuzzy sets of output, the highest degrees of relevance of each median of treatments were calculated, thus associating the input variables with the output variables. From the input variables it was possible to create 12 pairs of rules (Water Type $\times$ Level of N\%) and associated with the 7 output variables.

\section{Inference and Defuzzification Method}

In the fuzzy system, we used the inference method proposed by Mamdani and Assilian (1975) since antecedent and consequent are fuzzy propositions and, according to Ross (2010), it is the most common method found in the literature.

Defuzzification of the fuzzy model was carried out by the centroid method, which is the most used and generates the closest results to those observed by Yen \& Langari (1999), Ross (2010), Lababidi \& Baker (2006). Calculations can be made using [eq. (2)]:

$y=\frac{\sum_{x} \mu_{a}(x) x}{\sum_{x} \mu_{a}(x)}$

\section{Method of validation of the model}

From the verification of the assumptions, it was possible to perform the multiple regression analysis. Thus, the water type and the sewage sludge dose were adopted as variables of the equation, generating the generic model described by [eq. (3)]:

$y=a_{0}+a_{1} \cdot W T+a_{2} \cdot D S+a_{3} \cdot D S^{2}+a_{4} \cdot D S^{3}$ with $a_{i} \in \mathbb{R}, 1 \leq i \leq 4$,

Where:

$y$ - biometric variables analyzed;

$D S$ - dose of sewage sludge ( $\%$ of $\mathrm{N})$,

$W T$ - adopted water type.

For the comparison of the results obtained by the developed fuzzy model with the observed field, the following tests were used:

1. Mean squared error:

$E Q M=\sum_{i=1}^{n} \frac{\left(y_{\text {observed }}-y_{\text {fuzzy }}\right)^{2}}{n}$

2. Coefficient of determination $\mathrm{R}^{2}$ :

$R^{2}=1-\frac{\sum_{i=1}^{n}\left(y_{\text {fuzzy }}-y_{\text {observed }}\right)^{2}}{\sum_{i=1}^{n}\left(y_{\text {observed }}-y_{\text {fuzzy }}\right)^{2}}$

3. Willmott Index (Willmott et al., 1985):

$d=1-\left[\frac{\sum_{i=1}^{n}\left|y_{\text {fuzzy }}-y_{\text {observed }}\right|^{2}}{\sum_{i=1}^{n}\left(\left|y_{\text {fuzzy }}-\bar{y}\right|+\left|y_{\text {observed }}-\bar{y}\right|\right)^{2}}\right]$

Where:

$y_{\text {observed }}$ - data obtained experimentally;

$y_{f u z z y}$ - data estimated by the fuzzy model,

$\bar{y}$ - average of the observed values.

It should be noted that the closer the value of $R^{2}$ is to 1 , the better the model. For the analysis of the Willmott Index, the closer to 1 is the $d$, the greater the accuracy of the model.

\section{RESULTS AND DISCUSSION}

\section{Theoretical Results}

From TABLE 3, it was possible to determine the points of the membership functions of each fuzzy set. In the present model, 5 functions were adopted, denoted by VL, L, $\mathrm{M}, \mathrm{H}$ and $\mathrm{VH}$. It is important to note that, for the present model, only the variables that fit the polynomial regression model were considered. 


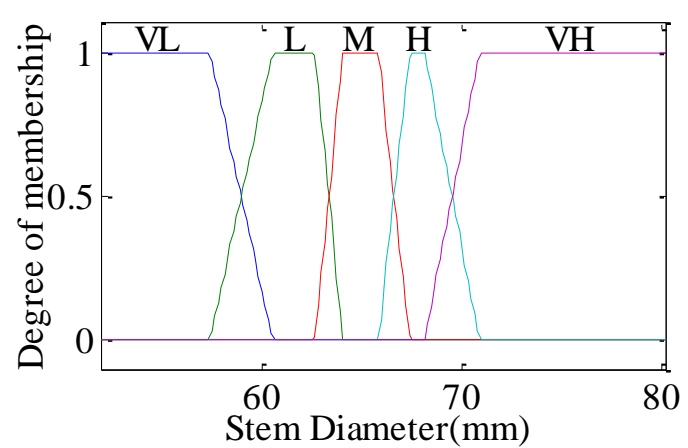

(a)

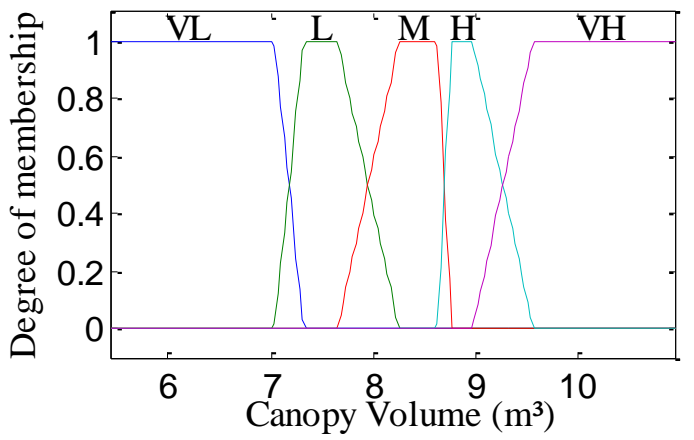

(c)

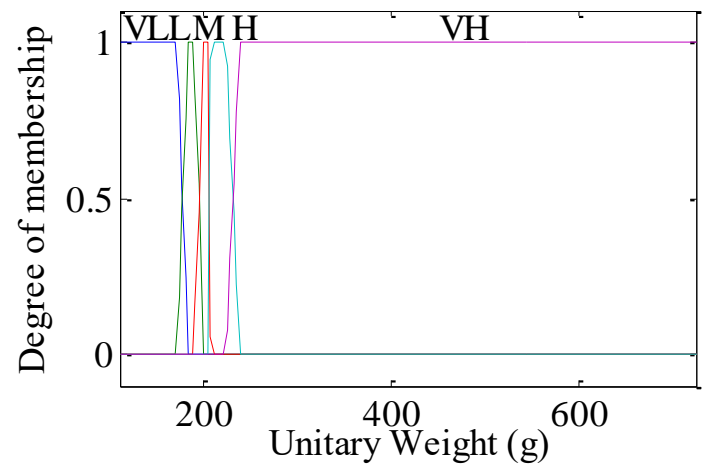

(e)

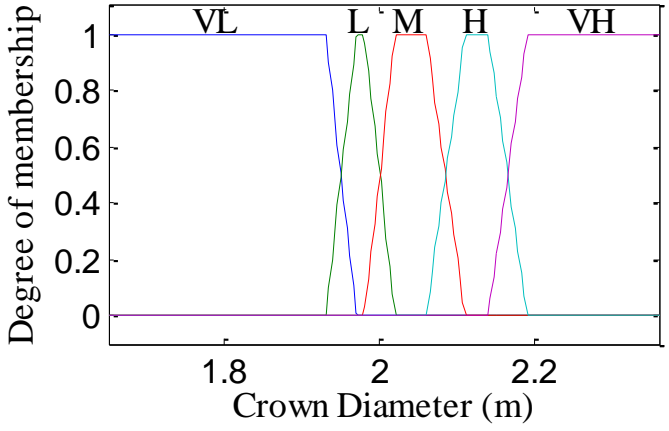

(b)

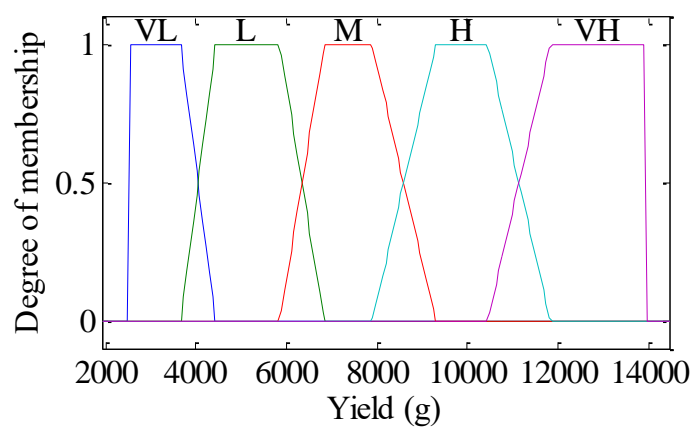

(d)

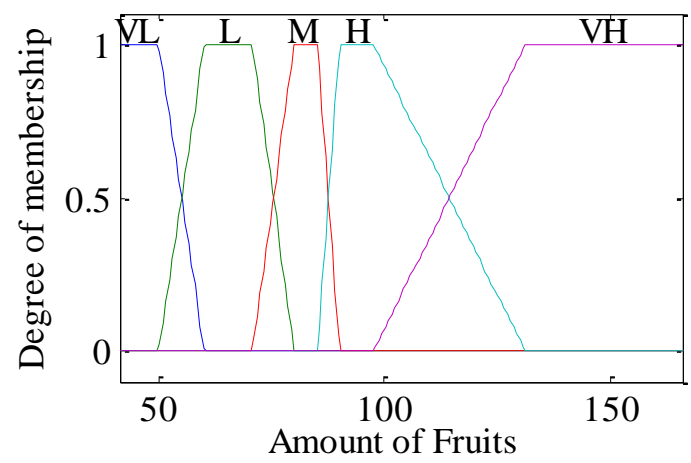

(f)

FIGURE 4. Fuzzy sets membership functions for the output variables of the orange crop submitted to irrigation with potable water and wastewater, and at different levels of nitrogen doses. (a) stem diameter, (b) crown diameter, (c) crown volume, (d) production, (e) unit weight and (f) number of fruits.

After the elaboration of the membership functions of each fuzzy set of the output variables, it was possible to build the rule base. The procedure adopted, as described by Cremasco et al., (2010), verified the highest degree of relevance associated with the median of treatment. Thus, it was verified in which fuzzy set the answer was contained (TABLE 4). 
TABLE 4. Rule base elaborated from the fuzzy system for the culture of oranges submitted to different doses of sewage sludge and types of water.

\begin{tabular}{|c|c|c|c|c|c|c|c|c|c|c|c|c|c|}
\hline \multicolumn{2}{|c|}{ Input variables } & \multicolumn{12}{|c|}{ Output variables } \\
\hline $\begin{array}{l}\text { Water } \\
\text { Type }\end{array}$ & $\begin{array}{l}\text { Sludge } \\
\text { doses }\end{array}$ & $\begin{array}{c}\text { Stem } \\
\text { diameter } \\
(\mathrm{mm})\end{array}$ & $\begin{array}{l}\text { Canopy } \\
\text { diameter } \\
(\mathrm{m})\end{array}$ & $\begin{array}{l}\text { Plants } \\
\text { height } \\
(\mathrm{m})\end{array}$ & $\begin{array}{c}\text { Canopy } \\
\text { volume } \\
\left(\mathrm{m}^{3}\right)\end{array}$ & $\begin{array}{l}\text { Number } \\
\text { of fruits }\end{array}$ & $\begin{array}{l}\text { Fruits } \\
\text { weight } \\
\text { (g) }\end{array}$ & Yield & $\begin{array}{l}\text { Fruits } \\
\text { weight } \\
\text { (g) }\end{array}$ & $\begin{array}{l}10 \text { fruits } \\
\text { weight } \\
(\mathrm{g})\end{array}$ & $\begin{array}{c}\text { Juice } \\
(\mathrm{ml})\end{array}$ & $\begin{array}{l}\text { Orange } \\
\text { juice } \\
\text { weight } \\
(\mathrm{g}) \\
\end{array}$ & $\begin{array}{c}\text { Orange } \\
\text { peel } \\
\text { weight } \\
(\mathrm{g}) \\
\end{array}$ \\
\hline WW & $0 \%$ & MB & MB & MB & MB & MB & MB & $\mathrm{B}$ & B & B & M & M & MB \\
\hline WW & $25 \%$ & B & M & B & B & M & A & M & B & M & M & M & B \\
\hline WW & $50 \%$ & M & M & B & M & M & MB & B & A & A & A & M & M \\
\hline WW & $75 \%$ & A & MA & A & MA & A & M & A & M & M & M & M & M \\
\hline WW & $100 \%$ & A & M & M & A & MA & A & MB & B & B & M & MB & M \\
\hline WW & $125 \%$ & M & MB & MB & MB & MB & M & B & MA & MA & M & A & MA \\
\hline PW & $0 \%$ & B & A & A & M & MA & MA & MA & MB & MB & MB & B & MB \\
\hline PW & $25 \%$ & M & B & M & A & B & M & M & M & A & MA & MA & M \\
\hline PW & $50 \%$ & M & M & M & A & B & M & A & M & B & $\mathrm{M}$ & B & B \\
\hline PW & $75 \%$ & $\mathrm{M}$ & MA & $\mathrm{M}$ & A & B & B & $\mathrm{M}$ & $\mathrm{M}$ & A & $\mathrm{M}$ & $\mathrm{M}$ & A \\
\hline PW & $100 \%$ & $\mathrm{M}$ & B & $\mathrm{M}$ & $\mathrm{M}$ & $\mathrm{M}$ & B & M & MA & A & $\mathrm{M}$ & M & MA \\
\hline PW & $125 \%$ & MA & $\mathrm{M}$ & M & B & A & B & M & M & $\mathrm{M}$ & M & M & A \\
\hline
\end{tabular}

Description: Wastewater (WW), potable water (PW).

Regression analysis was performed for all output variables, thus generating multiple polynomial models. In the present work, fuzzy models were created only for variables with significant regression analysis $(\mathrm{p}<0.05)$. The variables are shown in Table 5, bellow.

TABLE 5. Polynomial regression model parameters for the variables that fit the model.

\begin{tabular}{|c|c|c|c|c|c|c|}
\hline \multirow[t]{2}{*}{ Variable } & \multicolumn{6}{|c|}{$y=\beta_{0}+\sum_{j=1} \sum_{i=1} a_{i j} x_{j}^{i}$} \\
\hline & $\beta_{0}$ & $a x_{1}$ & $a_{1} x_{2}$ & $a_{2} x_{2}^{2}$ & $a_{3} x_{2}^{3}$ & $\mathrm{R}^{2}$ \\
\hline S.D. & 58.8 & 0.89 & 14.52 & -9.24 & 2.90 & 0.53 \\
\hline C.D. & 1.90 & 0.04 & 0.28 & 0.28 & -0.40 & 0.54 \\
\hline C.V. & 7.07 & 0.54 & 3.65 & 0.28 & 2.21 & 0.65 \\
\hline W.F. & 173.7 & 44.8 & -341 & 1013 & 570.1 & 0.57 \\
\hline N.F. & 94.9 & 5.2 & -161.6 & 263.3 & -94.8 & 0.37 \\
\hline Y. & 7733 & 1710 & -1297 & -36 & -152 & 0.48 \\
\hline
\end{tabular}

Description: Stem Diameter (S.D.), Crown Diameter (C.D.), Canopy Volume (C.V.), Number of Fruits (N.F.).

\section{Simulation of the model}

The increase in the concentration of sewage sludge doses led to a larger stem diameter (Figure 5). Plants grown in the presence of WW irrigation at the lowest doses of $\mathrm{N}(0$ and $25 \% \mathrm{~N}$ ) show a greater increase in their diameter. With intermediate doses $(50.75$ and $100 \% \mathrm{~N})$, it was found that treatments with DW had better performance, and at higher doses the largest diameter was with WW. 


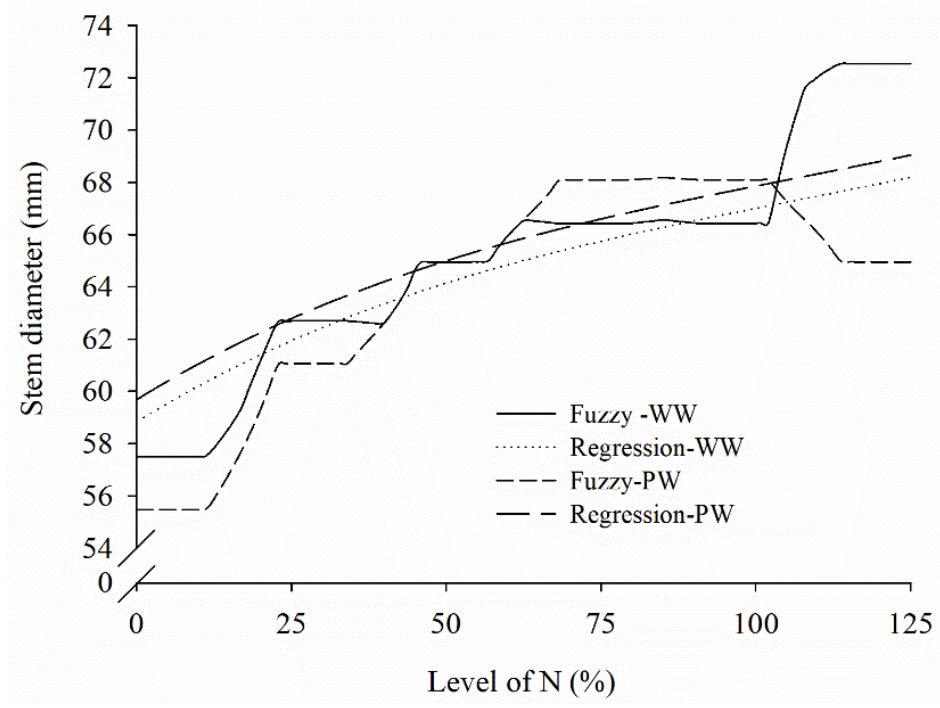

FIGURE 5. Stem diameter of the orange crop submitted to different doses of sewage sludge and wastewater modeled through the use of the fuzzy model and by regression analysis.

The canopy diameter of the orange plant showed a behavior similar to the diameter (Figure 6a). Regarding the crown volume, it was found that the behavior was similar to that of the crown diameter (Figure 6b). For the lowest doses,

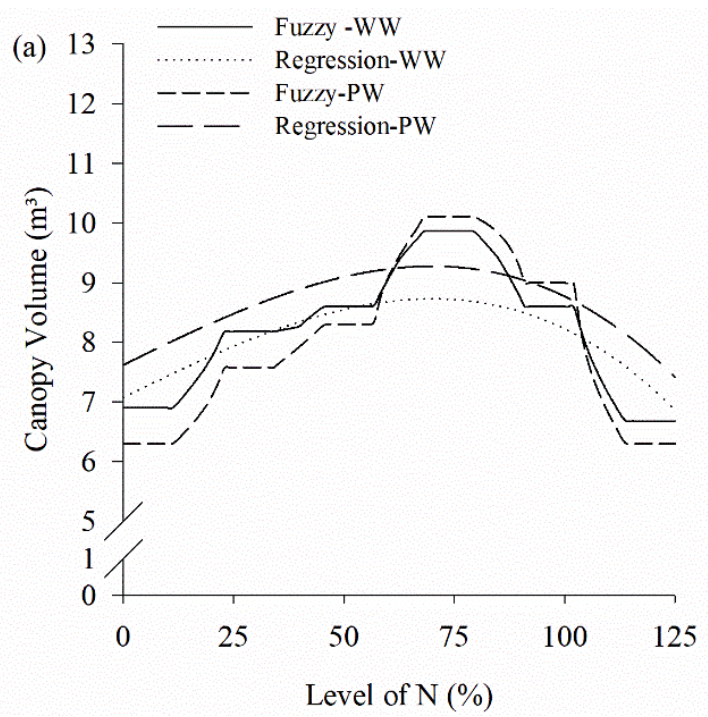

it was found that irrigation with WW led to a larger diameter and crown volume, while intermediate doses had the opposite effect. For higher doses, irrigation with WW showed the best performance.

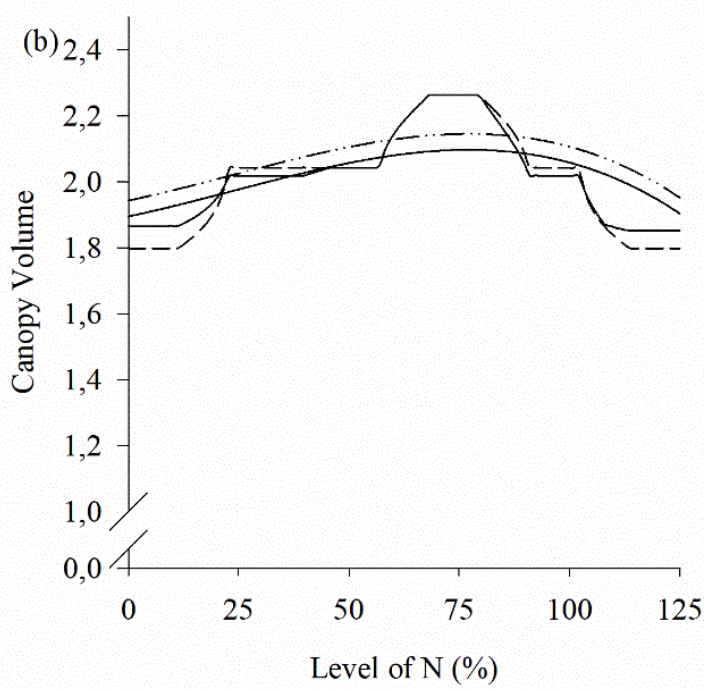

FIGURE 6. Cup diameter (a) and Cup volume (b) of the orange crop subjected to different doses of sewage sludge and wastewater modeled through the use of the fuzzy model and by regression analysis.

Production was higher for doses between 0 to $25 \%$ of $\mathrm{N}$, irrigated with $\mathrm{WW}$, reaching $9000 \mathrm{~kg}$, while when irrigated with DW, it reached only $500 \mathrm{~kg}$. In the ranges of 25 to $42 \%$ and 63 to $82 \%$ of N, it was observed that the production was higher when irrigated with DW. In other intervals, it was found that the production was higher when irrigated with WW. 


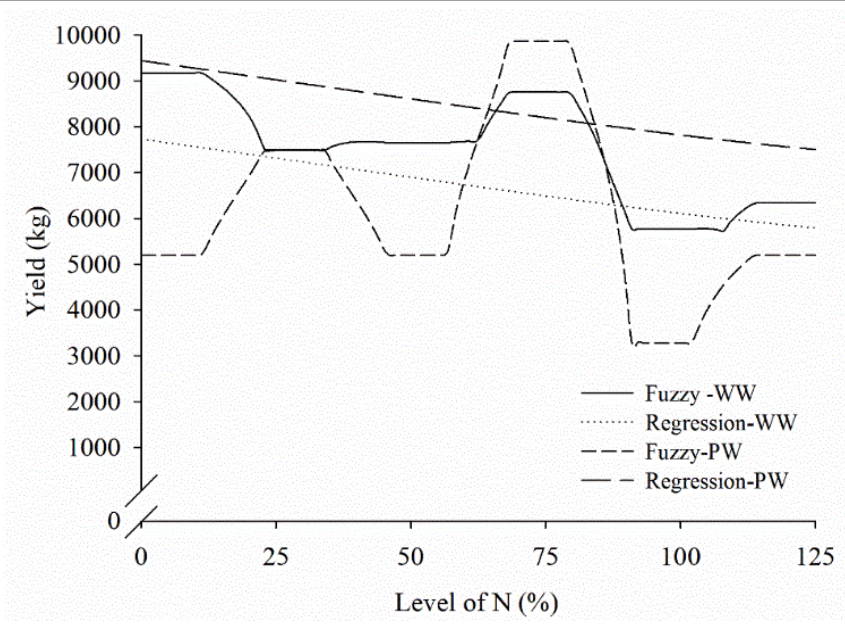

FIGURE 7. Production of orange culture submitted to different doses of sewage sludge and wastewater modeled through the use of the fuzzy model and by regression analysis.

The average weight of the fruits submitted to doses up to $75 \%$ was practically the same with WW irrigation. Above the value of $75 \%$, there was an abrupt increase in the average weight. The behavior was similar with DW irrigation, but for the $100 \%$ dose (Figure 8a).

The average number of fruits shows an increasing behavior from the initial dose to the $100 \%$ dose, with its value decreasing after this last dose. In addition, the $100 \%$ dose for both types of water showed the highest peak in fruit numbers. It is interesting to note that after the $100 \%$ dose, the increase in sewage sludge doses in the presence of potable water or wastewater causes a reduction in the number of fruits, but on the other hand, there is an increase in the average weight of the fruit.
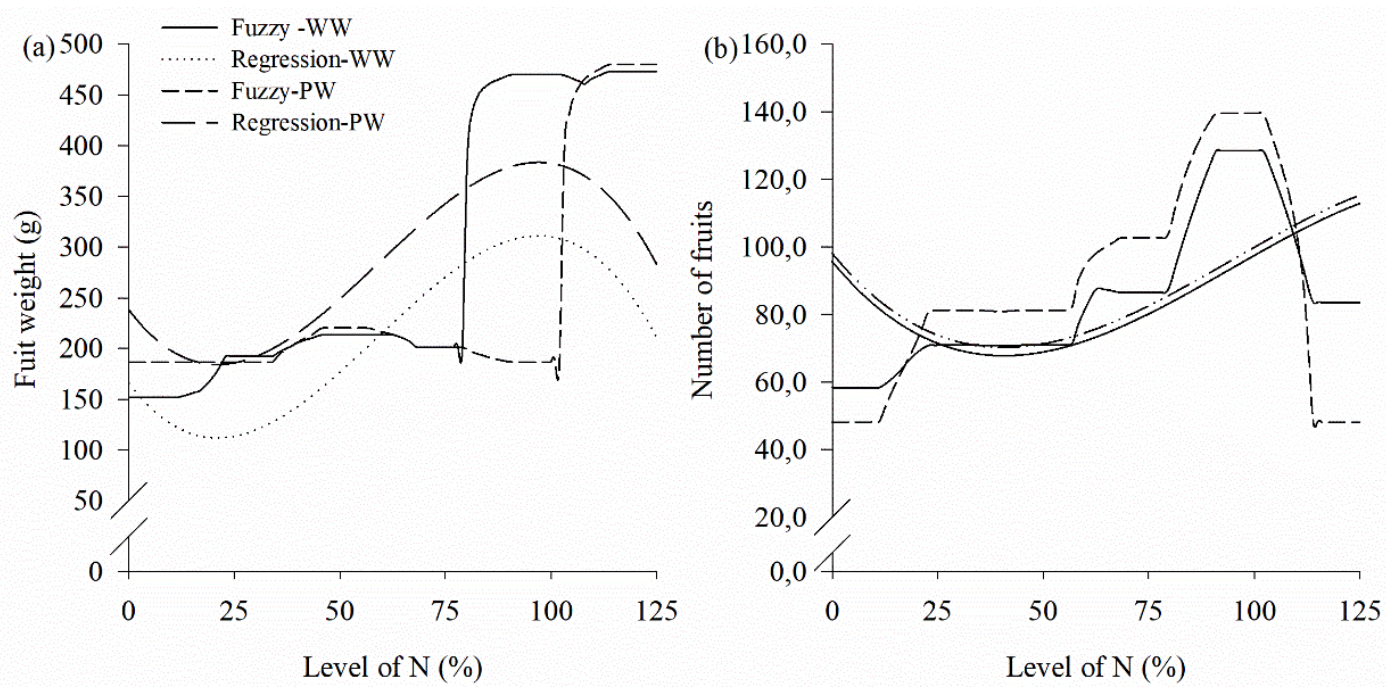

FIGURE 8. Fruit Weight (a) and Number of Fruits (b) of the orange plants subjected to different doses of sewage sludge and wastewater modeled through the use of the fuzzy model and by regression analysis.

The use of sewage sludge to meet plant $\mathrm{N}$ requirements had effects similar to those of $\mathrm{N}$ mineral supply (Smith et al., 1954; Alva et al., 1998; Bertonha et al., 2008). Therefore, it can be used in place of mineral fertilization of $\mathrm{N}$.

We also observed that WW irrigation promotes greater yields in sweet orange plants of the cultivar 'Valencia', wherein irrigation is more efficient when $\mathrm{N}$ is applied (Sharples \& Hilgeman, 1969). When studying irrigated citrus orchards, Orpanos \& Eliades (1994) observed the same effect on fruit weight as ours, which is closely related to soil water contents (Hilgeman, 1977).

The parameters stem diameter, canopy volume, and canopy diameter showed a point of the highest value, from which averages tend to decrease quadratically. This may be due to the high availability of $\mathrm{N}$ or other elements, which might have led to phytotoxicity. Notably, sewage sludge has quite similar characteristics to the organic matter in the soil (Ajwa \& Tabatabai, 1994; Zbytniewski \& Buszewski, 2005).

Adequate $\mathrm{N}$ availability during the critical fruiting stage is important to ensure fruit production and quality mainly (Alva et al., 19987; Tucker et al., 1995). Thus, making biosolids available, together with irrigation with WW, favors citrus production. However, due to $\mathrm{N}$ behavior in organic matter, we could observe that $\mathrm{N}$ is more available at rates up to $75 \%$. Thereafter, it causes phytotoxicity or is even mineralized, leached, or volatilized, and hence unavailable to plants. 


\section{Validation of the proposed model}

After the construction of the model and its discussion more focused on agronomic effects, the model was validated through the application of sensitivity / accuracy tests, in order to identify the errors that such models would present, and also determined the errors of statistical models.

Table 6 shows the occurrence of the mean squared error (MSE), the highest coefficient of determination $\left(\mathrm{R}^{2}\right)$ and the highest Willmott's Index for all fuzzy models.

TABLE 6. Comparative analysis between fuzzy and regression models developed to analyze the influence of water type and doses of sewage sludge on orange cultivation.

\begin{tabular}{c|c|ccc}
\hline Variable & Model & MSE & $\mathrm{R}^{2}$ & $\mathrm{D}$ \\
\hline \multirow{2}{*}{ Stem diameter $(\mathrm{mm})$} & Fuzzy & 17.5 & $0: 59$ & 0.99521 \\
& Regression & 17.7 & 0.53 & 0.99517 \\
\hline \multirow{2}{*}{ Canopy diameter $(\mathrm{m})$} & Fuzzy & 0011 & 0.66 & 0994 \\
& Regression & 0012 & 0.68 & 0.984 \\
\hline \multirow{2}{*}{ Canopy volume $\left(\mathrm{m}^{3}\right)$} & Fuzzy & 0802 & 0.65 & 0.983 \\
& Regression & 0.839 & 0.66 & 0.953 \\
\multirow{2}{*}{ Yield } & Fuzzy & $2.69 \times 10^{6}$ & 0.925 \\
\hline \multirow{2}{*}{ Fruits weight $(\mathrm{g})$} & Regression & $4.32 \times 10^{6}$ & 0.88 & 0.911 \\
& Fuzzy & 4775 & 0.54 & 0.765 \\
\hline \multirow{2}{*}{ Number of fruits } & Regression & 12616 & 0.83 & 0.37 \\
\hline
\end{tabular}

The application of models based on fuzzy rules offered more accurate results in several other works: in plant growth models (Putti, 2017, in the determination of evapotranspiration (Cobaner, 2011, and in the determination of the risk of weed infestation (Bressan et al., 2008).

\section{CONCLUSIONS}

The fuzzy model developed in the present study had a greater adjustment when compared to polynomial regression models. Therefore, it can be used to investigate intervals not usually experienced in the field.

Sweet orange plants develop more when irrigated with reuse water. Also, higher nitrogen rates in the biosolid can have a phytotoxic effect or even make this nutrient unavailable for plants.

\section{ACKNOWLEDGMENTS}

The authors would like to thank the Minas Gerais State Agency for Research and Development for the scholarship grant (APQ-00498-16). Also, the São Paulo State University, by the postdoctoral granted to the first author (Process 408/2015), and the National Council for Scientific and Technological Development (CNPq) for the research productivity grants awarded to the first and last authors (Process \#303923/2018-0 (FFP) and \#315228/2020-2 (LRAGF)).

\section{REFERENCES}

Ajwa HA, Tabatabai MA (1994) Decomposition of different organic materials in soils. Biology and Fertility of Soils 18(3): 175-182. DOI: http://doi.org/10.1007/BF00647664

Alva AK, Paramasivam S, Graham WD (1998) Impact of nitrogen management practices on nutritional status and yield of Valencia orange trees and groundwater nitrate. Journal of Environmental Quality 27(4): 904-910. DOI: http://doi.org/10.2134/jeq1998.00472425002700040026x
Andrade CA, Boeira RC, Pires AMM Nitrogênio presente em lodo de esgoto e a resolução n. 375 do Conama In: Coscione A R, Nogueira TAR, Pires AMM (2010) Uso agrícola de lodo de esgoto: avaliação após a resolução $\mathrm{n}^{\circ}$ 375 do Conama. Botucatu, Editora FEPAF, p157-170.

Bedbabis S, Rouina BB, Boukhris M, Ferrara G (2014) Effect of irrigation with treated wastewater on soil chemical properties and infiltration rate. Journal of environmental management 133: 45-50. DOI: http://doi.org/10.1016/j.jenvman.2013.11.007.

Bedbabis S, Trigui D, Ahmed C B, Clodoveo M L, Camposeo S, Vivaldi G A, Rouina, BB (2015) Long-terms effects of irrigation with treated municipal wastewater on soil, yield and olive oil quality. Agricultural Water Management 160: 14-21. DOI:

http://doi.org/10.1016/j.agwat.2015.06.023

Bertonha A, Frizzone JA, Martins EN (2008) Irrigação e adubação nitrogenada na produção de laranja-pêra. Acta Scientiarum. Agronomy 21: 537-542. DOI: http://doi.org/10.4025/actasciagron.v21i0.4281

Blanco-Fernández A, Casals MR, Colubi A, Corral N, García-Bárzana M, Gil MA, González- Rodríguez G, López MT, Lubiano MA, Montenegro M, Ramos-Guajardo AB, La Rosa De Sá AS, Sinova B (2014) A distance-based statistical analysis of fuzzy number-valued data. International Jounal of Approximate Reasoning 55:14871501. DOI: http://doi.org/10.1016/j.ijar.2013.09.020

Bourioug M, Gimbert F, Alaoui-Sehmer L, Benbrahim M, Aleya L, Alaoui-Sossé B (2015) Sewage sludge application in a plantation: effects on trace metal transfer in soil-plant-snail continuum. Science of the Total Environment 502: 309-314. DOI: http://doi.org/10.1016/j.scitotenv.2014.09.022 
Bressan GM, Koenigkan LV, Oliveira VA, Cruvinel PE, Karam D (2008) A classification methodology for the risk of weed infestation using fuzzy logic. Weed Research 48(5): 470-479. DOI: http://doi.org/10.1111/j.13653180.2008.00647.x

Brion N, Verbanck, MA, Bauwens W, Elskens M, Chen M, Servais P (2015) Assessing the impacts of wastewater treatment implementation on the water quality of a small urban river over the past 40 years. Environmental Science and Pollution Research, 22(16): 12720-12736. DOI: http://doi.org/10.1007/s11356-015-4493-8

Cobaner M (2011) Evapotranspiration estimation by two different neuro-fuzzy inference systems. Journal of Hydrology 398: 292-302. DOI:

http://doi.org/10.1016/j.jhydrol.2010.12.030

Coppi R, Gil MA, Kiers HAL (2006) The fuzzy approach to statistical analysis. Computational Statistics \& Data Analysis 51:1-14. DOI:

http://doi.org/10.1016/j.csda.2006.05.012

Costa FX, Lima VLA, Beltrão NEDM, Azevedo CAV, SOARES F, Alva IDM (2009) Efeitos residuais da aplicação de biossólidos e da irrigação com água residuária no crescimento do milho. Revista Brasileira de Engenharia Agrícola e Ambiental 13(6): 687-693. DOI: http://doi.org/10.1590/S1415-43662009000600004

Cremasco CP, Gabriel Filho LRA, Cataneo A (2010) Methodology for determination of fuzzy controller pertinence functions for the energy evaluation of poultry industry companies. Energia na Agricultura 259(3):21-39. DOI: http://doi.org/10.17224/EnergAgric.2010v25n1p21-39

Donoso JM, Rios-Touma B (2020) Microplastics in tropical Andean rivers: A perspective from a highly populated Ecuadorian basin without wastewater treatment. Heliyon 6(7): e04302. DOI:

http://doi.org/10.1016/j.heliyon.2020.e04302

Embrapa. Centro Nacional de Pesquisa de Solos. Sistema Brasileiro de Classificação de Solos. 2 ed. Rio de Janeiro: Embrapa Solos, 2006.

Gabriel Filho LRA, Cremasco CP, Putti FF, Chacur MGM (2011) Application of fuzzy logic for the evaluation of livestock slaughtering. Engenharia Agrícola 31(4):813825. DOI: http://doi.org/10.1590/S010069162011000400019

Gabriel Filho LRA, Pigatto GAS, Lourenzani AEBS (2015) Fuzzy rule-based system for evaluation of uncertainty in cassava chain. Engenharia Agrícola 35(2):350-367. DOI: http://doi.org/10.1590/1809-4430Eng.Agric.v35n2p350-367/2015

Gabriel Filho LRA, Putti FF, Cremasco CP, Bordin D, Chacur MGM, Gabriel LRA (2016) Software to assess beef cattle body mass through the fuzzy body mass index. Engenharia Agrícola 36(1): 179-193. DOI: http://doi.org/10.1590/1809-4430-

Eng.Agric.v36n1p179-193/2016

Góes BC, Goes RJ, Cremasco CP, Gabriel Filho LRA (2021) Fuzzy modeling of vegetable straw cover crop productivity at different nitrogen doses. Modeling Earth Systems and Environment, 7. DOI:

http://doi.org/10.1007/s40808-021-01125-4..
Herrera V (2019) Reconciling global aspirations and local realities: Challenges facing the Sustainable Development Goals for water and sanitation. World Development 118: 106-117. DOI:

http://doi.org/10.1016/j.worlddev.2019.02.009

Hilgeman RH (1977) Response of citrus trees to water stress in Arizona. In: International Society of Citriculture, Proceedings...

Kalavrouziotis IK, Pedrero F, Skarlatos D (2016) Water and wastewater quality assessment based on fuzzy modeling for the irrigation of Mandarin. Desalination and Water Treatment 57(43): 20159-20168. DOI: http://doi.org/10.1080/19443994.2015.1110050

Kibena J, Nhapi I, Gumindoga W (2014) Assessing the relationship between water quality parameters and changes in landuse patterns in the Upper Manyame River, Zimbabwe. Physics and Chemistry of the Earth, Parts A/B/C, 67, 153-163. DOI: http://doi.org/10.1016/j.pce.2013.09.017

Lababidi HMS, Baker CGJ (2006) Fuzzy Modeling. In Sablani SS, Rahman MS, Datta AK, Mujumdar AS (Ed.). Handbook of Food and Bioprocess Modeling Techniques. Boca Raton: CRC Press/Taylor \& Francis Group. DOI: http://doi.org/10.1201/9781420015072

Latare AM, Kumar O, Singh SK, Gupta A (2014) Direct and residual effect of sewage sludge on yield, heavy metals content and soil fertility under rice-wheat system. Ecological engineering, 69: 17-24. DOI: http://doi.org/10.1016/j.ecoleng.2014.03.066

Lanza, M. H. Utilização de lodo de esgoto compostado e irrigação com água residuária em laranjeiras 'valência'. 2014 - 78 f. Dissertação (Mestrado em Irrigação e Drenagem) - Universidade Estadual Paulista Júlio de Mesquita Filho, Botucatu.

Ma SC, Zhang HB, Ma ST, Wang R, Wang GX, Shao Y, Li CX (2015) Effects of mine wastewater irrigation on activities of soil enzymes and physiological properties, heavy metal uptake and grain yield in winter wheat. Ecotoxicology and Environmental Safety 113: 483-490. DOI: http://doi.org/10.1016/j.ecoenv.2014.12.031

Mamdani EH, Assilian S (1975) An experiment in linguistic synthesis with a fuzzy logic controller. International Journal of Man-Machine Studies 7(1): 1-13. DOI: http://doi.org/10.1016/S0020-7373(75)80002-2

Martínez MP, Cremasco CP, Gabriel Filho LRA, Braga Junior SS, Bednaski AV, Quevedo-Silva F, Correa CM, Silva D, Padgett RCML (2020) Fuzzy inference system to study the behavior of the green consumer facing the perception of greenwashing. Journal of Cleaner Production, 242: 116064. DOI: http://doi.org/10.1016/j.jclepro.2019.03.060

Matulovic, M, Putti, FF, Cremasco, CP, \& Gabriel Filho, LRA. Technology 4.0 with 0.0 costs: fuzzy model of lettuce productivity with magnetized water. Acta Scientiarum. Agronomy, v. 43, p. e51384-e51384, 2021. 
Miller-Robbie L, Ramaswami A, Amerasinghe P (2017). Wastewater treatment and reuse in urban agriculture: exploring the food, energy, water, and health nexus in Hyderabad, India. Environmental Research Letters 12(7): 075005. DOI: http://doi.org/10.1088/1748-9326/aa6bfe

Papageorgiou EI, Markinos A, Gemptos T (2009) Application of fuzzy cognitive maps for cotton yield management in precision farming. Expert systems with Applications, 36(10): 12399-12413. DOI: http://doi.org/10.1016/j.eswa.2009.04.046

Passos Rangel OJ, Silva CA, Bettiol W, Dynia JF (2006) Efeito de aplicações de lodos de esgoto sobre os teores de metais pesados em folhas e grãos de milho. Revista Brasileira de Ciência do Solo 30(3): 583-594. DOI: http://doi.org/10.1590/S0100-06832006000300018.

Patel J, Patel H, Bhatt C (2014) Generalized Calibration of the Hargreaves Equation for Evapotranspiration under Different Climate Conditions. Soil \& Water Research 9(2). DOI: http://doi.org/10.17221/28/2013-SWR

Pereira DF, Bighi CA, Gabriel Filho LRA, Cremasco CPC (2008) Sistema fuzzy para estimativa do bem-estar de matrizes pesadas. Engenharia Agrícola 28(4):624-633. DOI: http://doi.org/10.1590/S0100-69162008000400002

Putti FF, Gabriel Filho LRA, Cremasco CP, Bonini Neto A, Bonini CSB, Reis AR (2017a) A Fuzzy mathematical model to estimate the effects of global warming on the vitality of Laelia purpurata orchids. Mathematical Biosciences 288:124-129. DOI:

http://doi.org/10.1016/j.mbs.2017.03.005

Putti FF, Gabriel Filho LRA, Silva AO, Ludwig R, Cremasco CP (2014) Fuzzy logic to evaluate vitality of catasetum fimbiratum species (Orchidacea). Irriga 19(3):405-413. DOI: http://doi.org/10.15809/irriga.2014v19n3p405

Putti FF, Kummer ACB, Grassi Filho H, Gabriel Filho LRA, Cremasco CP (2017b) Fuzzy modeling on wheat productivity under different doses of sludge and sewage effluent. Engenharia Agrícola 37(6):1103-1115. DOI: http://doi.org/10.1590/1809-4430-eng.agric.v37n6p1103$1115 / 2017$

Quaggio JA, Raij Bvan, Piza Junior CT (1996) Frutíferas. In: Raij B van et al. Recomendações de adubação e calagem para o Estado de São Paulo. Campinas, Instituto Agronômico, 2ed. p119-154.

Ross TJ (2010) Fuzzy logic with engineering applications. Chichester, John Wiley \& Sons, 3ed. 607p.

Shaheen SM, et al. (2014) Stabilization of sewage sludge by using various by-products: effects on soil properties, biomass production, and bioavailability of copper and zinc. Water, Air, \& Soil Pollution 225(7). DOI: http://doi.org/10.1007/s11270-014-2014-X

Sharples GC, Hilgeman RH (1969) Influence of differential nitrogen fertilization on production, trunk growth, fruit size and quality and foliage composition of "Valencia" orange trees in Central Arizona. In Proc. First International Citrus Symposium. Riverside, Proceedings...
Smith PF, Reuther W, Specht AW, Hrnciar G (1954)

Effect of Differential Nitrogen, Potassium, and Magnesium Supply to Young Valencia Orange Trees in Sand Culture on Mineral Composition Especially of Leaves and Fibrous Roots. Plant physiology 29(4): 349. DOI: http://doi.org/10.1104/pp.29.4.349

Song XD, Xue XY, Chen DZ, He PJ, Dai XH (2014)

Application of biochar from sewage sludge to plant cultivation: Influence of pyrolysis temperature and biochar-to-soil ratio on yield and heavy metal accumulation. Chemosphere 109: 213-220. DOI: http://doi.org/10.1016/j.chemosphere.2014.01.070

Tucker DPH, Alva AK, Jackson LK, Wheaton TA (1995) Nutrition of Florida citrus trees. Gainesville, University of Florida, p40.

Viais Neto DS, Cremasco CP, Bordin D, Putti FF, Silva Junior JF, Gabriel Filho LRA (2019a) Fuzzy modeling of the effects of irrigation and water salinity in harvest point of tomato crop. Part I: description of the method.

Engenharia Agrícola 39(3):294-304. DOI:

http://doi.org/10.1590/1809-4430-eng.agric.v39n3p294304/2019

Viais Neto DS, Cremasco CP, Bordin D, Putti FF, Silva Junior JF, Gabriel Filho LRA (2019b) Fuzzy modeling of the effects of irrigation and water salinity in harvest point of tomato crop. Part II: application and interpretation. Engenharia Agrícola, 39(3):305-14. DOI:

http://doi.org/10.1590/1809-4430-eng.agric.v39n3p305$314 / 2019$

Waqas M, Khan S, Qing H, Reid BJ, Chao C (2014) The effects of sewage sludge and sewage sludge biochar on PAHs and potentially toxic element bioaccumulation in Cucumis sativa L. Chemosphere 105: 53-61. DOI: http://doi.org/10.1016/j.chemosphere.2013.11.064

Yang CC, Prasher SO, Landry JA, Ramaswamy H S (2003) Development of a herbicide application map using artificial neural networks and fuzzy logic. Agricultural Systems 76(2): 561-574. DOI:

http://doi.org/10.1016/S0308-521X(01)00106-8

Yen J, Langari R (1999) Fuzzy logic: Intelligence, control, and information. Upper Saddle River, N.J: Prentice Hall.

Yuan H, Lu T, Wang Y, Chen Y, Lei T (2016) Sewage sludge biochar: Nutrient composition and its effect on the leaching of soil nutrients. Geoderma 267: 17-23. DOI: http://doi.org/10.1016/j.geoderma.2015.12.020

Zbytniewski R, Buszewski B (2005) Characterization of natural organic matter (NOM) derived from sewage sludge compost. Part 1: chemical and spectroscopic properties. Bioresource technology 96(4): 471-478. DOI: http://doi.org/10.1016/j.biortech.2004.05.018 